\title{
JEJAK BENCANA GEOLOGI PADA BEBERAPA SITUS VERTEBRATA BERUMUR PLISTOSEN DI CEKUNGAN SOA FLORES
}

\author{
Vestige of the Geological Disaster on Several Vertebrate Pleistocene Sites \\ In Soa Basin Flores
}

\author{
Unggul Prasetyo Wibowo', Ifan Yoga Pratama Suharyogi', \\ Agustina Djafar ${ }^{1}$, Erick Setiyabudi
}

\author{
${ }^{1}$ Museum Geologi \\ Jalan Diponegoro No. 57, Bandung 40121 \\ ${ }^{2}$ Pusat Survei Geologi \\ Jalan Diponegoro No. 57, Bandung 40121 \\ E-mail: uungpw@yahoo.com
}

\begin{abstract}
Soa Basin is geographically located at 08 39'00" $S-08^{\circ} 46^{\prime} 00^{\prime \prime} S$ and $121^{\circ} 03^{\prime} 00^{\prime \prime} E-$ $121^{\circ} 13^{\prime} 00^{\prime \prime} E$ and is administratively located in Ngada Regency and Nagekeo Regency, Flores Island, Nusa Province East Southeast. This area has sites of Pleistocene paleontological vertebrates where one of the famous finds is the fossil of a mandible and teeth similar to Homo floresiensis at the Matamenge site. The purpose of this paper is to inventory the locations of these sites and identify evidence of traces of geological disasters in the Soa Basin. The methods used consisted of literature studies and field surveys. In general, these sites in the past show that there had been disasters recorded in rock layers of the Early Pleistocene and Middle Pleistocene ages.
\end{abstract}

Keywords: Pleistocene site, geological disaster, vertebrate fossil, Soa Basin, Flores

\begin{abstract}
Abstrak
Cekungan Soa secara geografis terletak pada koordinat $08^{\circ} 39^{\prime} 00^{\prime \prime}$ LS - 08 46'00" LS dan $121^{\circ} 03^{\prime} 00^{\prime \prime}$ BT $-121^{\circ} 13^{\prime}$ 00" BT dan secara administratif terletak di Kabupaten Ngada dan Kabupaten Nagekeo, Pulau Flores, Provinsi Nusa Tenggara Timur. Kawasan ini memiliki situssitus paleontologi vertebrata berumur Pleistosen dimana salah satu temuan yang terkenal adalah fosil rahang bawah dan gigi mirip manusia purba Homo floresiensis di situs Matamenge. Tujuan dari pembuatan makalah ini adalah untuk menginventarisir lokasi situs-situs dan mengidentifikasi bukti-bukti jejak bencana geologi di Cekungan Soa. Metode yang digunakan terdiri dari studi literatur dan survei lapangan. Secara umum situs-situs tersebut pada masa lalu menunjukkan pernah terjadi bencana yang terekam pada lapisan-lapisan batuan berumur Pleistosen Awal dan Pleistosen Tengah.
\end{abstract}

Kata kunci: situs pleistosen, bencana geologi, fosil vertebrata, Cekungan Soa, Flores

\section{PENDAHULUAN}

Pulau-pulau di Nusa Tenggara Timu,r seperti Flores, Sumba dan Timor terletak hampir tepat di tengah-tengah antara wilayah benua Asia Tenggara (Sunda) dan Australia (Sahul) (Aziz \& Morwood, 2009; O’Connor et al., 2011; Wibowo et al., 2018). Kondisi ini membuat Kepulauan Nusa Tenggara Timur secara geografis berada 
pada perbatasan budaya dan Bahasa, antara Asia dan Melanesia (Gambar 1). Hal ini terlihat dari penampilan fisik masyarakat yang bervariasi seperti di Flores Tengah biasanya berkulit gelap dan berpenampilan Melanesia, sedangkan yang lain, seperti komunitas pelaut di sekitar pantai, lebih khas Asia.

Flores terletak di tengah sistem Busur Gunung Api Banda, serangkaian gunung berapi dan pulau-pulau vulkanik yang menggambarkan zona subduksi aktif antara Lempeng Hindia dan Eurasia (Hall, 2002). Penunjaman di Lempeng India telah menyebabkan pengangkatan dan vulkanisme di sepanjang tepi selatan Lempeng Eurasia yang mengakibatkan munculnya serangkaian pulau vulkanik dan pembentukan palung laut dalam di selatan (Hall, 2001; Kopp et al., 2006).

Vulkanisme awal yang membentuk Flores terjadi pada saat masih di bawah permukaan laut (Burrett et al., 1991). Selama Miosen Tengah, batupasir dan batugamping diendapkan di bawah permukaan laut dalam cekungan yang mengelilingi pusat vulkanik Flores dimana selanjutnya aktivitas vulkanik berikutnya menghasilkan breksi vulkanik yang tersebar luas. Pada Miosen Akhir-Awal Pliosen, batugamping yang diselingi dengan material vulkanik telah diendapkan. Selanjutnya magmatisme terus berlanjut pada Pliosen-Pleistosen dan membentuk banyak kaldera (Koesoemadinata et al., 1994; van Bemmelen, 1949). Pusat aktifitas volkanik yang terletak tepat di sebelah barat laut Cekungan Soa yang aktif sekitar 2,5 juta tahun yang lalu tampaknya merupakan aktifitas volkanik yang membentuk breksi andesitik yang luas yang membentuk batuan dasar Cekungan Soa. Peristiwa ini berlanjut sampai setidaknya 1,66 juta tahun yang lalu (Muraoka et al., 2002). Peristiwa selanjutnya terjadi bencana-bencana volkanik dimana serangkaian tufa apung dasit diendapkan sebagai ignimbrites di Cekungan Soa. Produk-produk volkanik ini dalam proses pengendapannya tumpang tindih dengan endapan-endapan lakustrin dan sedimen fluviatil pada Pleistosen Awal dan Tengah. 


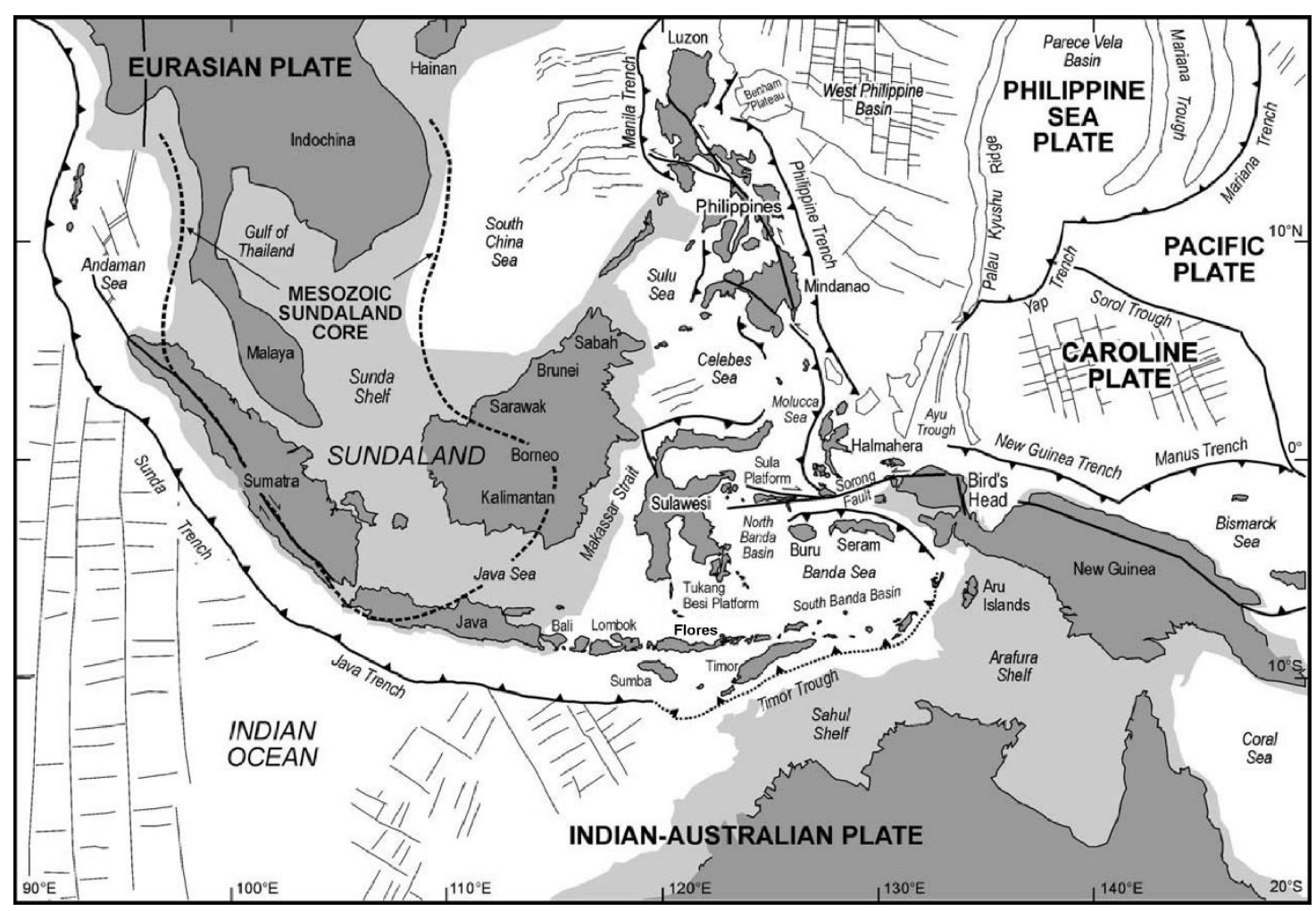

Gambar 1. Tatanan Geologi Kepulauan Indonesia (Hall, 2002).

Sepanjang sejarah Flores, aktivitas vulkanisme dan laju pengangkatan tektonik menjadi faktor dominan dalam membentuk lanskap pulau. Fluktuasi permukaan laut, terkait dengan siklus glasial dan interglasial juga menyebabkan penyesuaian dasar sistem Sungai Ae Sissa sebagai sungai utama di Cekungan Soa. Lebih lanjut baik akumulasi dan erosi vertikal sedimen Cekungan Soa sangat dipengaruhi oleh laju pengangkatan tektonik dan drainase sungai dimana kadang-kadang aliran sungai dalam Cekungan Soa tersebut terhalang oleh proses volkanik membentuk danau-danau.

Cekungan Soa secara geografis terletak pada koordinat $08^{\circ} 39^{\prime} 00^{\prime \prime} \mathrm{LS}-08^{\circ} 46^{\prime}$ 00" LS dan $121^{\circ} 03^{\prime} 00^{\prime \prime}$ BT - $121^{\circ} 13^{\prime} 00^{\prime}$ " BT dan secara administratif terletak di Kabupaten Ngada dan Kabupaten Nagekeo, Pulau Flores, Provinsi Nusa Tenggara Timur. Cekungan Soa merupakan cekungan antar gunung, yang dibatasi oleh Kaldera Welas di sebelah utara, Gunung Inielika di sebelah barat, Gunung Ebulobo di sebelah selatan dan Gunung Keli Lambo di sebelah timur (Djafar et al., 2018). Dalam dekade terakhir Cekungan Soa dikenal dengan ditemukannya artefak dan fosil baik fosil megafauna maupun fosil hominid (Brumm et al., 2016; van den Bergh et al., 2016). Berdasarkan hal tersebut maka tujuan tulisan ini adalah untuk menginventarisir lokasi situs-situs dan mengidentifikasi bukti-bukti jejak bencana geologi terutama gunung api di Cekungan Soa. Metode yang digunakan terdiri dari studi literatur dan survei lapangan. 


\section{PEMBAHASAN}

\section{Stratigrafi Cekungan Soa}

Morfologi Cekungan Soa umumnya merupakan dataran rendah dengan sebaran bukit-bukit kecil dan lembah-lembah terjal. Bukit-bukit kecil tersebut berbentuk kerucut dengan puncak membulat atau rata, tersebar tidak teratur berdiri sendiri atau berjejer membentuk punggungan dengan kenampakan memanjang (Gambar 2). Ketinggian bukit-bukit tersebut berkisar antara 300 - 410 meter di atas muka laut (Djafar et al., 2018). Karakter morfologi ini merupakan cerminan dari batuan yang menyusun Cekungan Soa dan sekitarnya.

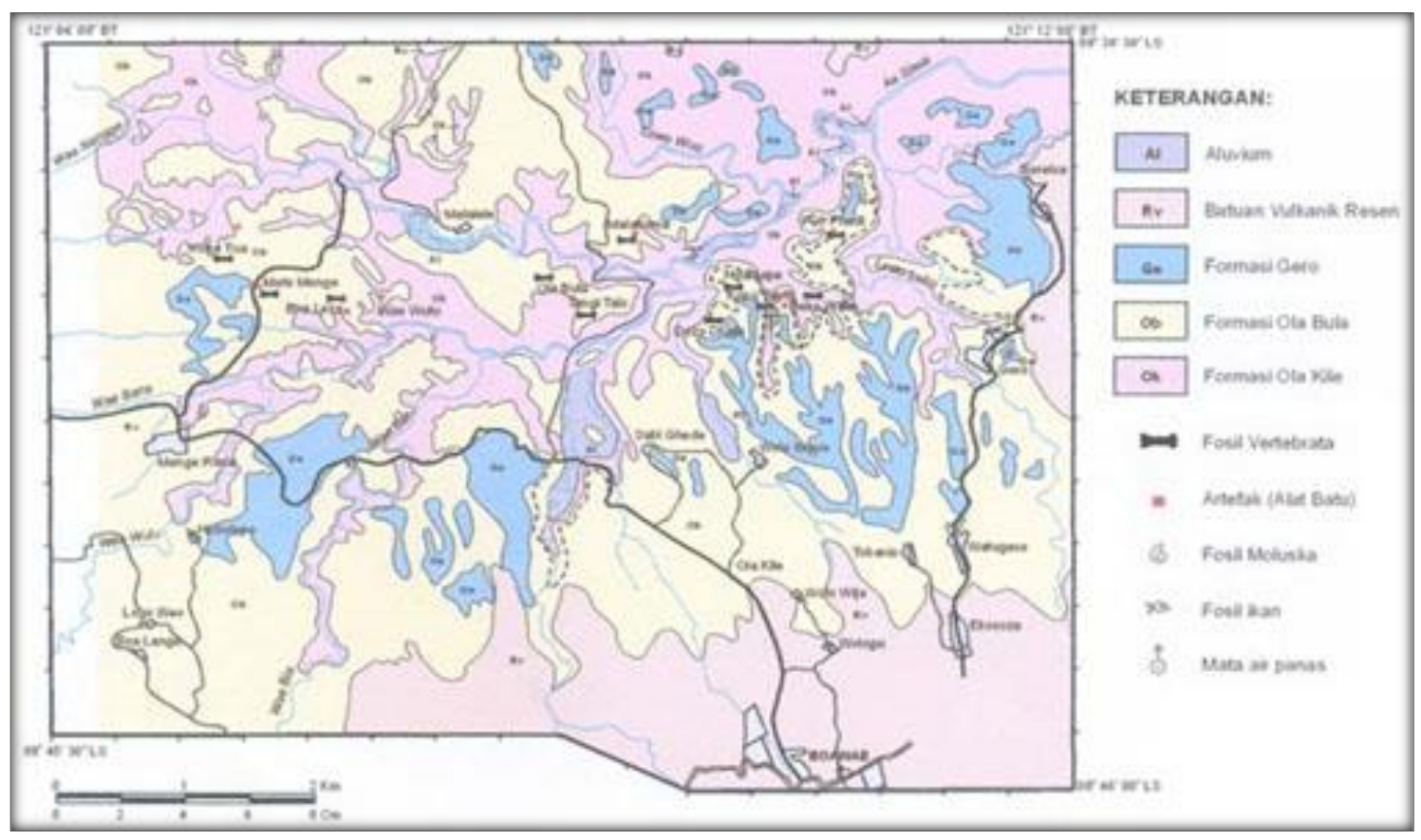

Gambar 2: Peta Geologi Cekungan Soa. (Sumber: Suminto et al., 2009).

Menurut (Aziz \& Morwood, 2009) stratigrafi Cekungan Soa dari tua ke muda terdiri dari:Formasi Olakile yang terdiri dari breksi volkanik dengan sisipan batupasir dan batulanau tufan, serta lava andesit, berumur Pliosen (Gambar 2). Hal ini menunjukkan bahwa di dasar Cekungan Soa mungkin terdapat gunung api yang muncul setelah terbentuk Kaldera Purba Soa. Formasi Olakile ini kemudian secara tidak selaras ditindih oleh Formasi Olabula, bagian bawah terdiri dari anggota tufa, bagian tengah terdiri dari anggota batu pasir tufaan, lanau tufaan dan kerikil batuapung (pumis) tengah) serta bagian atas tediri dari anggota batu gamping Gero yang terdiri dari perselingan lapisan batugamping dan tuf karbonatan, mengandung moluska berumur Plistosen Awal - Plistosen Tengah. Di dalam Formasi Ola Bula ini di beberapa tempat dijumpai artefak dan fosil-fosil vertebrata (Gambar 2).

Anggota Gero tersusun oleh laminasi batugamping (Suminto et al., 2009). Dari banyak pengamatan diyakini bahwa batugamping ini terbentuk di lingkungan air tawar. 
Dalam proses pengendapan kedudukan batugamping Gero mengikuti permukaan topografi awal, sebarannya tidak merata serta perlapisannya tidak menerus. Apabila topografi awal datar maka batugamping Gero akan membentuk perlapisan horisontal, tetapi jika permukaan awal membentuk tebing atau lereng maka bidang perlapisan batugamping Gero juga miring sesuai kemiringan topografi awal.

\section{Situs-Situs Plistosen Cekungan Soa}

Cekungan Soa memiliki beberapa lokasi utama situs paleontologi-arkeologi seperti Tangitalo, Boalesa, Wolosege dan Matamenge (Gambar 3). Salah satu lokasi yang cukup dikenal adalah situs Matamenge. Situs Matamenge dikenal karena merupakan tempat ditemukannya fosil rahang bawah dan gigi mirip manusia purba yang secara anatomi mirip Homo floresiensis (van den Bergh et al., 2016). Manusia purba Cekungan Soa ini ditemukan di lokasi Matamenge di lapisan Formasi Ola Bula (Gambar 3). Homo floresiensis sendiri merupakan jenis manusia purba kerdil yang ditemukan di gua Liang Bua Flores dengan tinggi sekitar $1 \mathrm{~m}$, volume otak $380 \mathrm{~cm}$ (Brown et al., 2004).

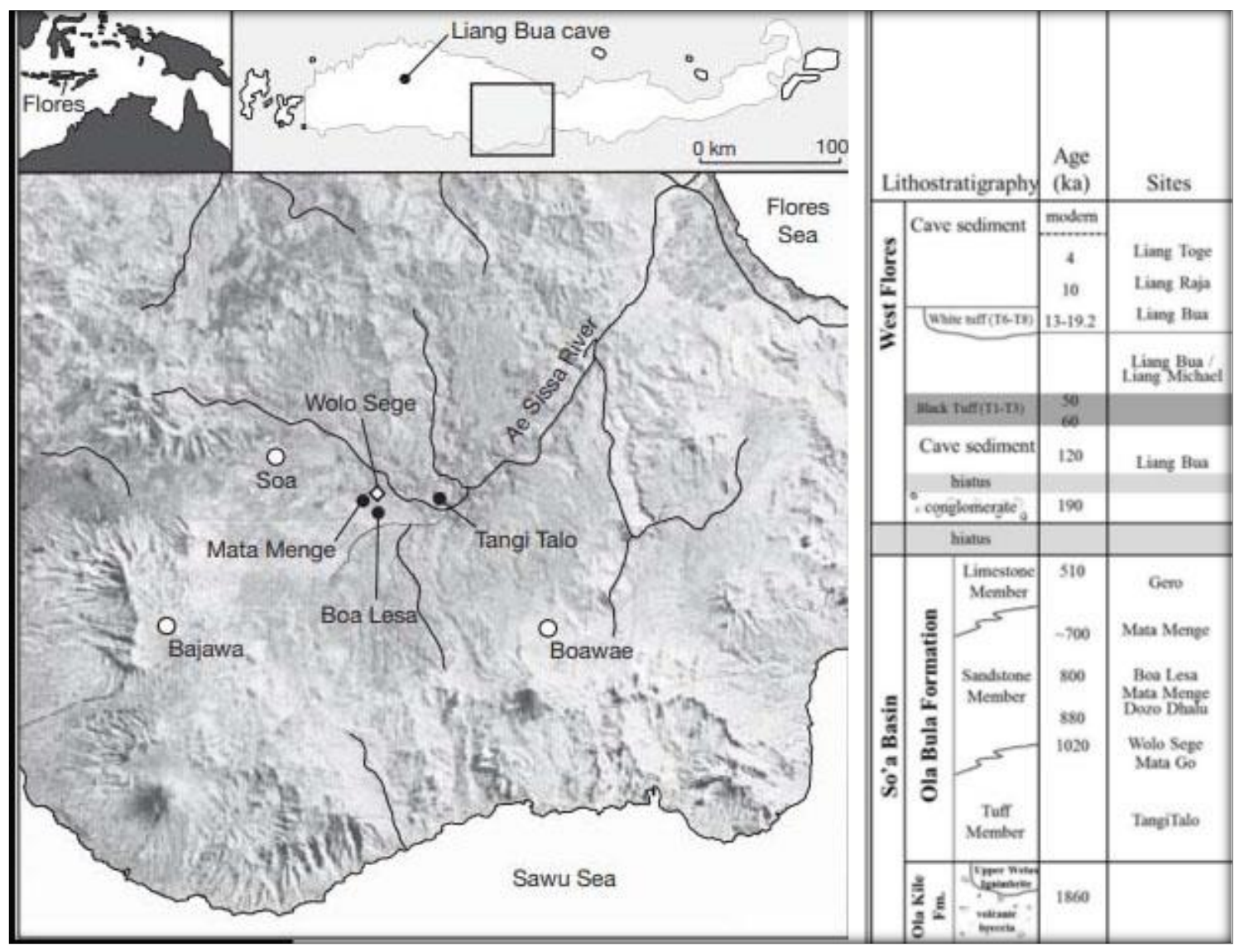

Gambar 3. Beberapa lokasi utama situs paleontologi-arkeologi di Cekungan Soa, Flores (modifikasi dari Brumm et al., 2010). 


\section{Situs Tangitalo}

Tangi Talo merupakan situs fosil tertua yang terletak pada $8^{\circ} 41^{\prime} 55^{\prime \prime} \mathrm{LS}, 121^{\circ} 08^{\prime}$ 10"BT, 416 meter di atas permukaan laut (dpl) di Cekungan Soa. Fosil-fosil ditemukan dalam interval tufan bagian bawah dari Formasi Ola Bula. Fosil-fosil yang ditemukan berupa sisa-sisa fosil stegodon kerdil Stegodon sondaari, kurakura raksasa dan komodo pada endapan lahar. Batuan pengandung fosil ini berumur lebih dari 1 juta tahun yang lalu (Puspaningrum et al., 2014). Tidak ada artefak batu in situ yang ditemukan dalam penggalian, dan pada bukti saat ini situs tersebut mendahului kedatangan hominin di cekungan.

\section{Situs Wolosege}

Wolo Sege terletak di $8^{\circ} 41^{\prime} 26^{\prime}$ ' LS, $121^{\circ} 5$ ' 59" BT pada interval tuf yang teralterasi, ignimbrite dan endapan batuapung yang lapuk di dasar Formasi Ola Bula. Di sini ditemukan artefak batu berumur 1 juta tahun yang lalu (Brumm et al., 2010). Umur absolut didasarkan pada analisa Argon Argon dimana sampel diambil dari lapisan produk volkanik ignimbrite di atas lapisan paleosol di lokasi Wolosege. Lapisan ignimbrite ini kemudian menjadi lapisan kunci yang diberi nama ignimbrite Wolosege.

\section{Situs Boa Lesa}

Boa Lesa berada pada $8^{\circ} 41^{\prime} 46.6^{\prime \prime} \mathrm{LS}, 121^{\circ} 06^{\prime} 02.8^{\prime}$ 'BT di perbukitan kecil di tengah-tengah semenanjung antara dua ngarai anak Sungai Ae Bha. Deposit fosil ditemukan pada Formasi Ola Bula di lereng bukit tersebut dengan umur lapisan sekitar 840.000 tahun yang lalu berdasarkan analisa umur lapisan tuffa di lokasi (O’Sullivan dkk., 2001).

\section{Situs Matamenge}

Situs ini berada pada $8^{\circ} 41^{\prime} 30.1^{\prime \prime}$ LS, $121^{\circ} 05^{\prime} 38.7$ 'BT di Formasi Ola Bula. Ketebalan Formasi Ola Bula di Mata Menge sekitar $40 \mathrm{~m}$. Interval paling atas berupa lapisan batugamping tipis Gero, dengan ketebalan $9 \mathrm{~m}$. Interval berisi fosil fosil vertebrata, hominin dan artefak berada pada lapisan batupasir setebal kurang dari $30 \mathrm{~cm}$ terkonsolidasi dengan baik, berbutir halus sampai sedang, dan mengandung laminasi paralel di bagian bawahnya, serta banyak kerikil vulkanik dengan sudut relatif membundar. Lapisan batupasir ini tertutup oleh lapisan lahar diatasnya, sedangkan alas dari lapisan batupasir adalah palaeosol yang terkonsolidasi dan berkembang dengan baik dengan tebal kurang lebih 6,5 m. 


\section{Paleosol}

Di dalam perlapisan batuan gunung api, baik yang termasuk Formasi Olakile maupun Formasi Olabula, batas kontak antara kedua formasi, bahkan di antara batuan gunung api resen terdapat tubuh tanah purba. Tubuh tanah purba dapat dijumpai di situs Boalesa, Wolosege, dan Matamenge. Pembentukan tanah purba itu menunjukkan bahwa pada waktu itu kegiatan gunung api mengalami istirahat, tidak terjadi sedimentasi sehingga permukaan batuan yang ada mengalami pelapukan menjadi tubuh tanah. Semakin tebal tubuh tanah menggambarkan lamanya waktu istirahat kegiatan gunung api. Semakin lama waktu istirahat dan semakin tebal tubuh tanah terbentuk maka semakin berkembang kehidupan flora dan fauna di daerah itu.
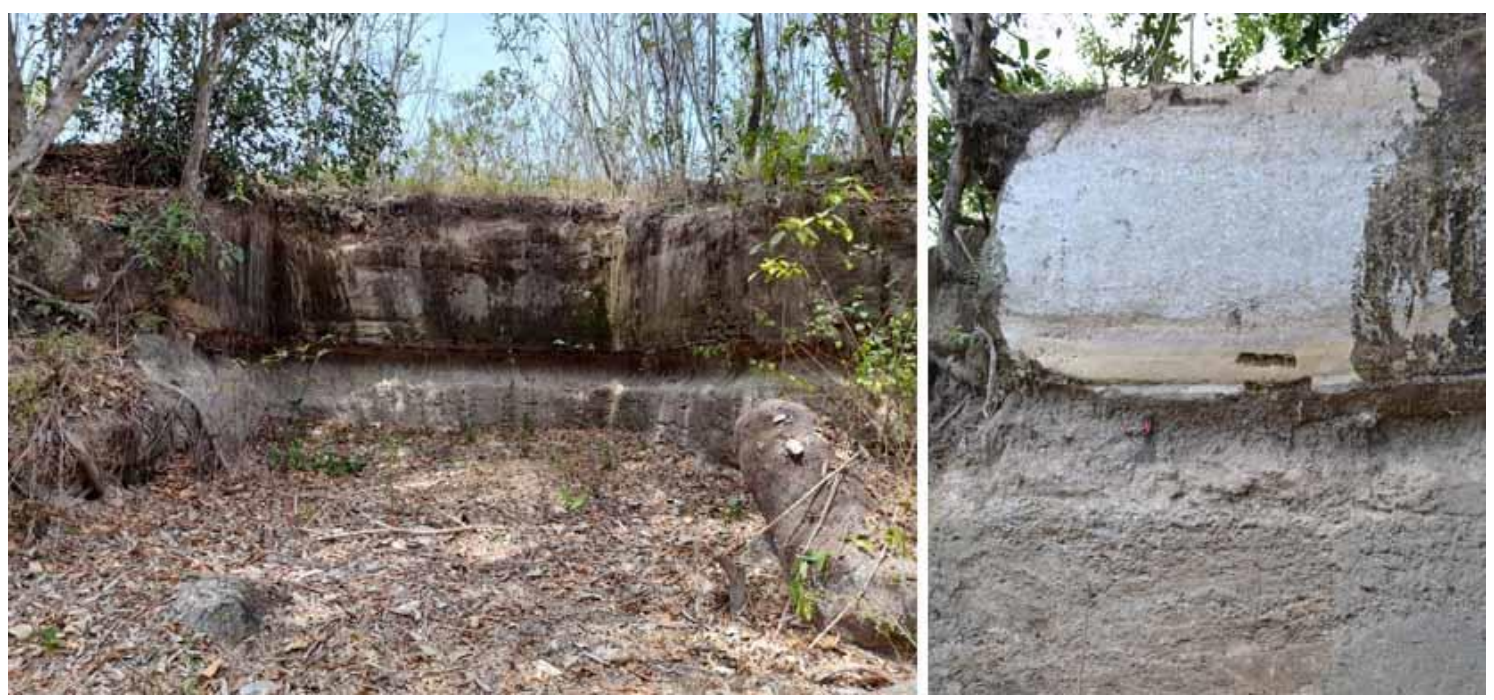

Gambar 4. Kiri: lokasi Wolosege; Kanan: lapisan ignimbrite (atas) dan lapisan paleosol (bawah) di lokasi Wolosege (Sumber: Dokumentasi Unggul Prasetyo Wibowo).

Walaupun di permukaan terlihat damai, akan tetapi magma di bawah gunung api sebenarnya masih aktif dan berdiferensiasi mulai dari magma basal, menjadi andesit dan dasit atau bahkan riolit (magma asam). Semakin asam magma yang terbentuk terjadi pembentukan gas gunung api (bahan volatil) semakin banyak dan semakin bertekanan tinggi. Letusan besar pembentukan kaldera gunung api terjadi apabila tekanan gas gunung api sudah lebih besar dari tekanan batuan penutupnya. Pada waktu itulah tanah pelapukan terlanda dan sekaligus tertutup oleh batuan piroklastika yang sangat tebal yang disebut tefra, ignimbrit dan produk volkanik lainnya. Pada saat itulah binatang yang hidup di atas tanah pelapukan terlanda dan mati terkubur oleh produk-produk volkanik tersebut.

Pada musim hujan sebagian sebagian endapan volkanik tersebut tererosi bersama-sama dengan fosil binatang dan artefak untuk kemudian terendapkan kembali di dalam endapan sungai atau fluviatil. Itulah sebabnya sebagian fosil dan artefak ditemukan di dalam endapan piroklastika/ignimbrit dan sebagian berada di dalam endapan fluvium. Dengan dijumpainya lapisan-lapisan tanah purba yang berselingan 
dengan lapisan-lapisan pengandung fosil mengindikasikan bahwa adanya beberapa periode kehidupan sekaligus pemusnahan kehidupan di Cekungan Soa.

\section{Aspek Gunungapi Cekungan Soa}

Analisis dan interpretasi citra satelit menunjukan bahwa Cekungan Soa merupakan suatu kaldera gunungapi purba (Kaldera Soa) yang dikelilingi oleh gunung api tua dan gunung api aktif masa kini. Di bagian selatan deretan gunung api aktif Inie Rie, Inie Lika. Di antara kedua gunung api aktif itu terdapat banyak kerucut gunung api monogenesis yang membentuk kerucut sinder dan kerucut lava dan tersebar di sekitar kota Bajawa Di sisi timur Cekungan Soa terdapat gunung api aktif Ebulobo. Di bagian barat terdapat Kaldera Welas dan di bagian utara berupa batuan gunung api tua, yang diduga sebagai sisa dari gunung api purba Soa. Batuan G. Ebulobo dan batuan gunung api tua itu tersingkap baik di daerah Boawae (Kabupaten Ngada), ke utara sampai dengan kota Mbay, Kabupaten Nagakeo.

Beberapa gunungapi yang produknya mengisi Cekungan Soa, yaitu: Kelompok gunung api aktif masa kini di daerah Bajawa-Mataloko di tepi barat daya Cekungan Soa; G. Wolomese, terletak di sebelah barat Cekungan Soa; Kaldera Welas, terletak di tepi baratlaut Cekungan Soa; Gunung api purba Soa, yang sisanya tubuhnya terletak di bagian utara, antara lain wilayah Desa Nagarawe, Kabupaten Nagakeo; Gunung Api Kelilambo di bagian timur laut; Gunung Api Ratongamobho di bagian timur; Gunung Api Ebulobo, yang merupakan Gunung Api aktif masa kini, terletak di tepi selatan Cekungan Soa dan gunung api di antara Gunung Ebulobo dengan Kompleks Gunung Api Mataloko-Bajawa. 


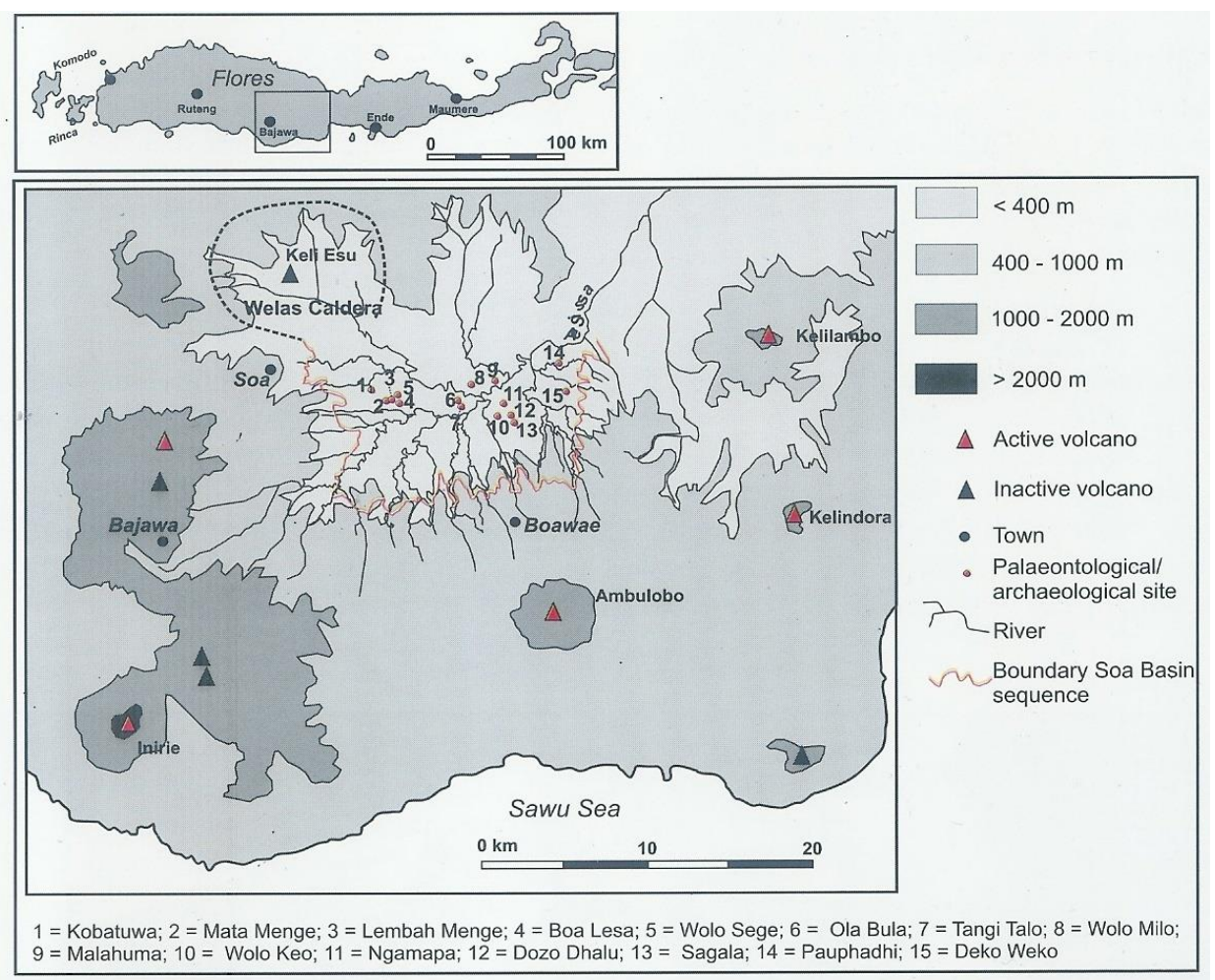

Gambar 5. Kompleks volkanik pengisi Cekungan Soa (Aziz, dkk. 2009).

\section{Gunung Api di dasar Cekungan Soa}

Hartono (1961) dan Suminto et al. (2009) menyatakan bahwa sebagai batuan dasar di Cekungan Soa adalah Formasi Olakile. Formasi ini tersusun oleh breksi gunung api dengan sisipan batupasir dan batulanau tufan serta lava andesit. Dari hasil penyelidikan awal ini diketahui bahwa breksi gunung api itu secara asal-usul terdiri atas breksi piroklastika, aglomerat, breksi lahar dan breksi, konglomerat serta batupasir sebagai endapan rombakan di lingkungan sungai (endapan fluvium). Breksi piroklastika, lahar dan rombakan dapat berasal dari gunung api di tepi Cekungan Soa seperti yang disebutkan di atas. Akan tetapi keberadaan aglomerat menunjukkan bahwa batuan piroklastika itu secara in situ berasal dari dasar Cekungan Soa. Hal ini menunjukan adanya kegiatan gunung api tua (volkanisma) di Cekungan Soa ini. Bukti yang paling kuat adanya gunung api purba di dasar Cekungan Soa adalah ditemukannya aliran lava basal - andesit basal di aliran sungai Wolo Watu dan Way Bha di sebelah timur Desa Mengeruda, dan aliran lava bongkah di mata air panas Mengeruda.

Di banyak tempat di Cekungan Soa terdapat beragam batuan ubahan hidrotermal yang membentuk limonit, hematit, batulempung putih, batuan karbonat serta terkersikkan. Batuan ubahan hidrotermal ini mengindikasikan bahwa di bawah Cekungan Soa terdapat sumber panas yang berinteraksi dengan air meteorik/ bawah permukaan mengakibatkan terjadinya proses hidrotermal (Gambar 6). 


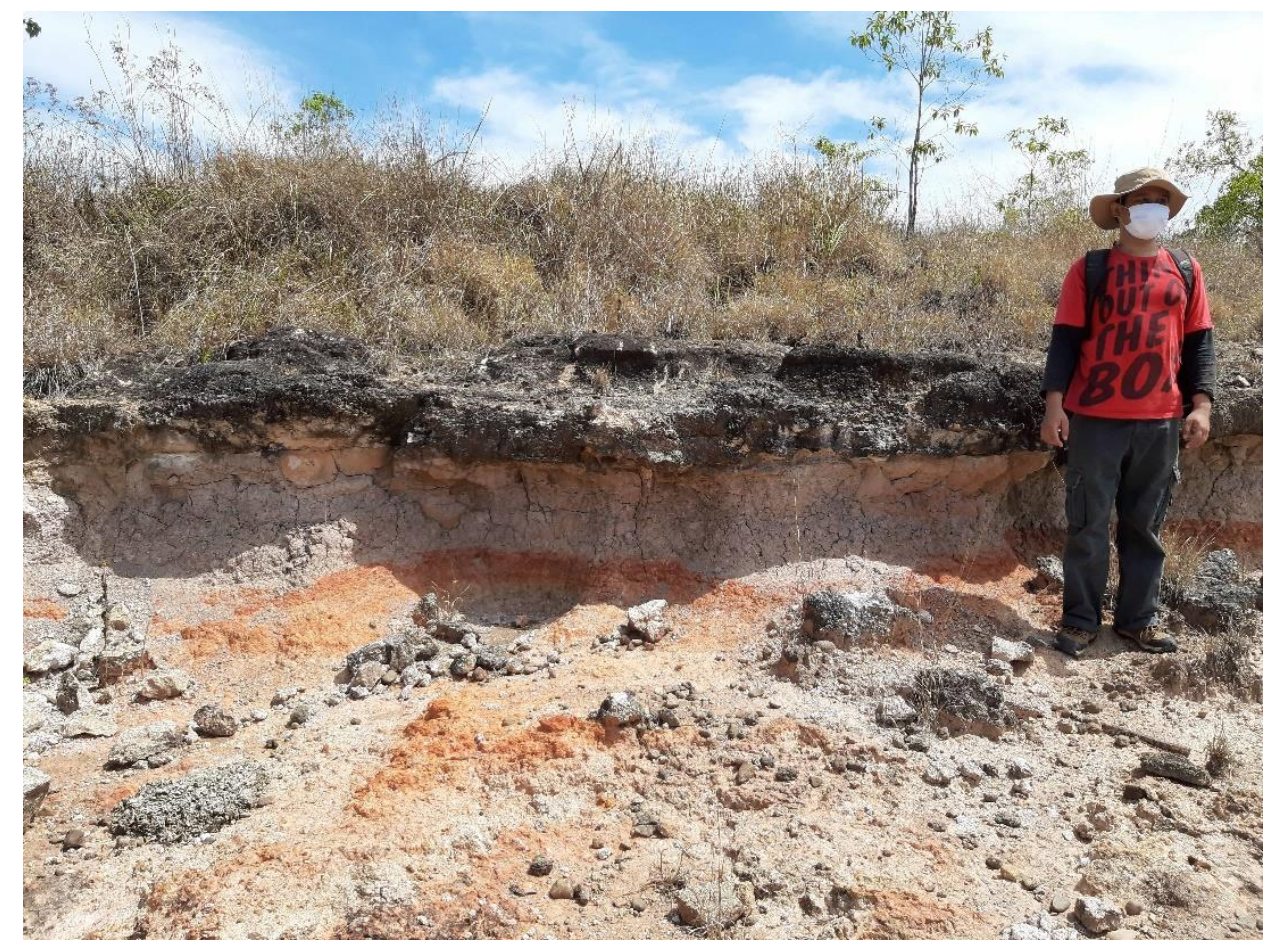

Gambar 6. Batuan menjadi kemerahan hasil alterasi hidrotermal (Sumber: Dokumentasi Unggul Prasetyo Wibowo).

\section{SIMPULAN}

Secara umum temuan fosil dan artefak berumur Plistosen di Cekungan Soa berasosiasi dengan endapan produk volkanik dan lapisan paleosol atau tanah purba. Hal tersebut menunjukkan bahwa pada masa lalu pernah terjadi beberapa kali periode kehidupan sekaligus pemusnahan kehidupan di Cekungan Soa akibat dari bencana gunungapi. Bencana gunungapi masif yang memusnahkan kehidupan tersebut terekam pada lapisan-lapisan batuan berumur Plistosen Awal dan Plistosen Tengah. Peristiwa erupsi masa lalu dapat menjadi cerminan bahwa bencana merusak dapat berdampak hebat pada lingkungan dan kehidupan manusia hingga tingkat pemusnahan sehingga pengetahuan akan hal ini dapat menjadi peringatan dalam usaha mencari upaya antisipatif di masa yang datang untuk dapat mengurangi faktor resiko dan dampak yang mungkin ditimbulkan di masa yang akan datang.

\section{DAFTAR PUSTAKA}

Aziz, F., \& Morwood, M. J. (2009). Introduction: Geology, palaeontology and archaeology of the Soa Basin, Central Flores, Indonesia. In F. Aziz, M. J. Morwood, \& G. D. van den Bergh (Eds.), Pleistocene Geology, Palaeontology, and Archaeology of the Soa Basin, Central Flores, Indonesia (pp. 1-18). Bandung: Pusat Survei Geologi.

Brown, P., Sutikna, T., Morwood, M. J., Soejono, R. P., Jatmiko, Saptomo, E. W., \& Due, R. A. (2004). A New small-bodied hominin from the Late Pleistocene of Flores, Indonesia. 
Nature, 431, 1055-1061. Diunduh 5 Maret 2010 pukul 15:12.

(https://doi.org/10.1038/nature02999)

Brumm, A., Bergh, G. D. van den, Storey, M., Kurniawan, I., Alloway, B. V., Setiawan, R., Setiyabudi, E., Grün, R., Moore, M. W., Yurnaldi, D., Puspaningrum, M. R., Wibowo, U. P., Insani, H., Sutisna, I., Westgate, J. A., Pearce, N. J. G., Duval, M., Meijer, H. J. M., Aziz, F., ... Morwood, M. J. (2016). Age and context of the oldest known hominin fossils from Flores. Nature, 534, 249-253. Diunduh Februari 2017 pukul 12:10. (https://doi.org/10.1038/nature17663)

Brumm, A., Jensen, G. M., van den Bergh, G. D., Morwood, M. J., Kurniawan, I., Aziz, F., \& Storey, M. (2010). Hominins on Flores, Indonesia, by one million years ago. Nature, 464(7289), 748-752. 6 Januari 2013 pukul 09:30 (https://doi.org/10.1038/nature08844)

Burrett, C., Berry, D. R., \& Varne, R. (1991). Asian and South-Western Pacific Continental Terranes derived from Gondwana, and their Biogeographic significance. Australian Systematic Botany, 4, 13-24.

Djafar, A., Suharyogi, I. Y. P., \& Wibowo, U. P. (2018). Identifikasi situs geologi Cekungan Soa - Flores, sebagai salah satu warisan geologi. Pertemuan Ilmiah Tahunan Ikatan Ahli Geologi Indoneisa / PIT IAGI.

Hall, R. (2001). Cenozoic reconstructions of SE Asia and the SW Pacific: Changing pattern of land and sea. In I. Metcalfe, J. M. B. Smith, M. Morwood, \& I. D. Davidson (Eds.), Faunal and Floral Migrations and Evolution in SE Asia-Australasia (pp. 35-56). Swets \& Zeitlinger.

Hall, R. (2002). Cenozoic geological and plate tectonic evolution of SE Asia and the SW Pacific: Computer-based reconstructions, model and animations. Journal of Asian Earth Sciences, 20, 353-431.

Hartono, H. M. S. (1961). Geological Investigation at Ola Bula, Flores. Bandung: Djawatan Geologi

Koesoemadinata, S., Noya, Y., \& Kadarisman, D. (1994). Peta Geologi Lembar Ruteng, Nusatenggara [Peta Geologi]. Bandung: Pusat Penelitian dan Pengembangan Geologi

Kopp, H., Flueh, E. R., Peterson, C. J., Weinrebe, W., Wittwer, A., \& Scientists, M. (2006). The Java margin revisited: Evidence for subduction erosion off Java. Earth and Planetary Science Letters, 242, 130-142.

Muraoka, H., Nasution, A., Urai, M., Takahashi, M., Takashima, I., Simanjuntak, J., Sundhoro, H., Aswin, D., Nanlohy, F., Sitorus, K., Takahashi, H., \& Koseki, T. (2002). Tectonic, volcanic and stratigraphic geology of the Bajawa geothermal field, central Flores, Indonesia. Bulletin of the Geological Survery of Japan, 53(2/3), 109-138.

O'Connor, S., Ono, R., \& Clarkson, C. (2011). Pelagic fishing at 42,000 years before the present and the maritime skills of modern humans. Science, 334, 1117-1121.

Puspaningrum, M. R., van den Bergh, G. D., Chivas, A., Setiabudi, E., Kurniawan, I., Brumm, A., \& Sutikna, T. (2014). Preliminary results of dietary and environmental reconstructions of Early to Middle Pleistocene Stegodonts from the So'a Basin of Flores, Indonesia, based on enamel stable isotope records. Abstract Book, Special volume 102, 164-165. Greece: Ristotle University of Thessaloniki.

Suminto, Morwood, M. J., Kurniawan, I., Aziz, F., Bergh, G. D. van den, \& Hobbs, D. R. (2009). Geology and fossil sites of the Soa Basin, Flores, Indonesia. dalam Pleistocene Geology, Palaeontology, and Archaeology of the Soa Basin, Central Flores, Indonesia (pp. 19-40). Bandung: Pusat Survei Geologi.

van Bemmelen, R. W. (1949). The Geology of Indonesia: Vol. I A. The Hague, Martinus Nijhoof.

van den Bergh, G. D., Kaifu, Y., Kurniawan, I., Kono, R. T., Brumm, A., Setiyabudi, E., Aziz, F., \& Morwood, M. J. (2016). Homo floresiensis-like hominin fossils from the early Middle Pleistocene of Flores. Nature, 534. Diunduh tanggal 5 januari 2017 pukul 13:15. (http://dx.doi.org/10.1038/nature17999). 
Wibowo, U. P., Handini, R., Simanjuntak, T., Sofian, H. O., \& Maulana, S. (2018). Geological approach in order to distinguish the preference source of the raw material from the megalithic tombs in East Sumba, Indonesia. Amerta, 36(2), 101-114. Diunduh tanggal 3 Januari 2019 pukul 10:15 (https://doi.org/10.24832/amt.v36i2.101-114)

\section{HASIL DISKUSI}

\section{Pertanyaan}

1. Ary Sulistyo (TACB Kota Depok)

Nilai Apa yang didapt dari hasil penelitian lingkungan yang telah dilakukan tersebut?

\section{Jawaban}

1. Ivan (Museum Geologi Bandung)

Peristiwa erupsi masa lalu dapat menjadi cerminan bahwa bencana merusak dapat berdampak hebat pada lingkungan dan kehidupan manusia sehingga dapat menjadi peringatan dan mencari upaya antisipatif di masa yang datang untuk dapat mengurangi faktor resiko dan dampak yang mungkin ditimbulkan di masa yang akan datang 